\title{
Развертывание вооруженных сил во время коронавирусного кризиса: соблюдение Кодекса поведения ОБСЕ?
}

\author{
Александр Ламберт, Филип Эйдус, Томас Шмидт*
}

\section{Аннотация}

Цель настоящей статьи - оценить, соблюдались ли при использовании европейскими странами вооруженных сил в условиях коронавирусного кризиса положения Кодекса поведения ОБСЕ, касающегося военно-политических аспектов безопасности, и других соответствующих документов ОБСЕ. В статье показано, что большинство мер, принятых государствамиучастниками ОБСЕ в ответ на пандемию COVID-19, до настоящего времени соответствовали нормам и обязательствам по ОБСЕ. В то же время в ходе исследования были выявлены слабые места, в частности, в том, что касается необходимости четко определять функции и задачи вооруженных сил и сил безопасности, а также гарантий безопасности, вытекающих из принципов необходимости, соразмерности и недискриминации в связи с мерами, принимаемыми в чрезвычайных ситуациях в государстве. Имело место также несколько случаев отступления от обязательств, связанных с уважением прав человека и основных свобод. Мы предлагаем рекомендации по укреплению в будущем соблюдения норм и обязательств по ОБСЕ в случаях использования вооруженных сил внутри страны для оказания содействия гражданским властям в чрезвычайных ситуациях.

Ключевые слова

Коронавирус, ОБСЕ, Кодекс поведения, касающийся военно-политических аспектов безопасности, вооруженные силы

Для цитирования этой публикации: Ламберт А., Эйдус Ф., Шмидт Т. Развертывание вооруженных сил во время коронавирусного кризиса: соблюдение Кодекса поведения ОБСЕ? // ОБСЕ Insights 5. - Баден-Баден: Номос, 2021. URL: https://doi.org/10.5771/9783748921264-05

* Александр Ламберт, доктор наук, Женевский институт геополитических исследований, Швейцария, lambert@geopolitics-geneva.ch

Филип Эйдус, доктор наук, Белградский университет, Сербия, filip.ejdus@fpn.bg.ac.rs Томас Шмидт, постоянное представительство Швейцарии при ОБСЕ, ООН и других международных организациях в Вене, Австрия, thomas.schmidt@eda.admin.ch 


\section{Введение ${ }^{144}$}

В конце 2019 года в провинции Ухань Китайской Народной Республики появилась атипичная вирусная пневмония. К началу 2020 года был идентифицирован возбудитель болезни - коронавирус SARS-CoV-2, а болезнь получила название COVID-19. 30 января Генеральный директор Всемирной организации здравоохранения (BО3) объявил вспышку этого заболевания чрезвычайной ситуацией в области общественного здравоохранения, имеющей международное значение. Вскоре вирус быстро распространился по всему миру. Для того, чтобы справиться с этой беспрецедентной чрезвычайной ситуацией в области здравоохранения, получившей название коронавирусного кризиса, большинство государств-участников ОБСЕ ввело режим чрезвычайного положения в той или иной форме, включая использование вооруженных сил.

Ожидается, что современные вооруженные силы как крупные и хорошо организованные структуры, обладающие значительной инфраструктурой, людскими и материальными ресурсами, будут участвовать в преодолении таких чрезвычайных ситуаций и оказывать гражданским властям содействие в периоды кризисов. Однако при этом они должны соблюдать не только конституционные рамки, в которых они действуют, но и международные нормы, регулирующие применение силы, в том числе принятые в ОБСЕ. Как организация по безопасности, ОБСЕ не занимается непосредственно вопросами здравоохранения и медицины. Тем не менее Кодекс поведения, касающийся военно-политических аспектов безопасности, принятый в 1994 году, содержит важные нормативные ориентиры для использования вооруженных сил в чрезвычайных ситуациях в области общественного здравоохранения, таких как коронавирусный кризис ${ }^{145}$. Данное обстоятельство особенно актуально с учетом того, что Кодекс имеет отношение как к военно-политическому, так и к гуманитарному измерению безопасности ${ }^{146}$.

Ключевой вопрос, рассматриваемый в настоящей статье, заключается в том, как использовались европейские вооруженные силы во время коронавирусного кризиса и соответствовало ли это использование нормам и обязательствам, принятым в рамках ОБСЕ. Статья начинается с обзора нормативных положений Кодекса поведения и других документов ОБСЕ, которые можно рассматривать как применимые к внутригосударственному использованию силы в чрезвычайных ситуациях в области общественного здравоохранения, таких как коронавирусный кризис. Затем мы анализируем, каким образом государства использовали свои вооруженные силы в условиях кризиса, и указываем на наиболее серьезные проблемы, связанные с соблюдением тех или иных норм ОБСЕ. Мы опираемся на официальные документы ОБСЕ и государств-участников, в том числе на официальные веб-сайты министерств обороны и вооруженных сил, страновые доклады Европейской организации военных ассоциаций и профсоюзов, научные труды и новостные сообщения. Наш анализ охватывает период с момента объявления чрезвычайной ситуации в области обществен- 
ного здравоохранения в связи с COVID-19 в январе 2020 года до начала сентября 2020 года, когда в большинстве европейских стран первая волна пандемии прошла. Что касается конкретных стран, мы рассматриваем действия, предпринятые европейскими государствами-участниками ОБСЕ. Наш анализ показывает, что, несмотря на очевидные риски, связанные как с использованием вооруженных сил внутри страны, так и с чрезвычайными ситуациями, рассмотренные страны в целом соблюдают нормы ОБСЕ, хотя и с некоторыми заметными исключениями. В заключение мы извлекаем уроки из коронавирусного кризиса и предлагаем политические рекомендации.

\section{Применимые нормы ОБСЕ}

Политически обязывающие документы ОБСЕ содержат ряд положений, применимых к использованию вооруженных сил во время коронавирусного кризиса. Первая группа положений, содержащихся в документах, которые имеют отношение к третьему, человеческому измерению безопасности ОБСЕ, связана с чрезвычайными ситуациями в государстве в целом. Документ Московского совещания Конференции по человеческому измерению ОБСЕ 1991 года ${ }^{147}$ (пункт 28.10) требует от государств-участников информировать СБСЕ ${ }^{148}$ об объявлении или отмене чрезвычайного положения, а также о любом отступлении от его международных обязательств в области прав человека в связи с объявлением чрезвычайного положения. На встрече на высшем уровне в Хельсинки в 1992 году ${ }^{149}$ было принято решение о том, что Бюро по демократическим институтам и правам человека (БДИПЧ) будет выполнять функции информационного центра ОБСЕ по вопросам, касающимся чрезвычайного положения. Пункты 24 и 25 Копенгагенского документа 1990 года касаются возможного отступления от обязательств, относящихся к правами человека и основными свободам, в условиях чрезвычайного положения ${ }^{150}$. Они недвусмысленно запрещают злоупотребления и произвольное применение ограничений прав человека и основных свобод и предусматривают, что законные ограничения и исключения должны соответствовать принципу соразмерности (пункт 24). В документе государства-участники подтвердили, что такие отступления недопустимы в отношении определенных прав даже во время чрезвычайного положения (или войны).

Наконец, пункт 25 Копенгагенского документа содержит конкретные положения, которые устанавливают принципы публичности (25.2), необходимости (25.3) и недискриминации (25.4) в случае объявления чрезвычайного положения. Что касается необходимости, документ предусматривает, что «меры, представляющие собой отступление от обязательств, будут строго ограничиваться рамками, которых требует острота положения». Что же касается недискриминации, то в пункте 25.4 говорится, что «такие меры не повлекут за собой дискриминации исключительно на ос- 
нове расовой принадлежности, цвета кожи, пола, языка, религии, социального происхождения или принадлежности к меньшинству» ${ }^{151}$.

Вторая группа положений документов ОБСЕ, применимых к коронавирусному кризису, касается применения вооруженных сил в целях обеспечения внутренней безопасности. Как упоминалось выше, основной источник нормативных положений ОБСЕ об использовании вооруженных сил - Кодекс поведения. Он содержит ряд дополнительных положений, касающихся развертывания вооруженных сил и сил безопасности в целях обеспечения внутренней безопасности, в частности, в целях обеспечения соблюдения режима чрезвычайного положения в государстве. Эти положения предусматривают, что такие действия должны соответствовать международным стандартам в области прав человека, в том числе стандартам, касающимся прав и основных свобод военнослужащих, дополняя тем самым упомянутые выше нормы в области человеческого измерения.

Среди пунктов Кодекса поведения наиболее прямое отношение к коронавирусному кризису имеют пункты 21, в котором подчеркивается важность конституционных рамок для обеспечения демократического контроля, 34, в котором говорится о необходимости соблюдения норм международного права, и 36-37, содержащие положения, касающиеся направления вооруженных сил для выполнения задач в области внутренней безопасности, включая упомянутый выше принцип пропорциональности в случае (возможного) применения силы. Поскольку эти пункты важны, приведем их:

21. Каждое государство-участник будет постоянно обеспечивать и поддерживать эффективное руководство и контроль над своими военными и военизированными силами и силами безопасности со стороны конституционно учрежденных органов власти, обладающих демократической легитимностью. Каждое государство-участник будет создавать рычаги, позволяющие обеспечить выполнение такими органами возложенных на них конституционных и правовых обязанностей. Государства-участники будут четко определять функции и задачи таких сил, а также их обязанность действовать исключительно в конституционных рамках.

34. Каждое государство-участник будет обеспечивать, чтобы в условиях как мирного, так и военного времени руководство, укомплектование личным составом, подготовка и оснащение его вооруженных сил отвечали положениям международного права.

36. Каждое государство-участник будет обеспечивать, чтобы любое решение о направлении его вооруженных сил для выполнения задач в области внутренней безопасности принималось в соответствии с конституционными процедурами. В таких решениях будут определяться задачи, поставленные перед вооруженными силами, и будет обеспечиваться, чтобы эти задачи выполнялись под эффективным контролем конституционно учрежденных органов власти и с соблюдением 
принципа верховенства закона. В случае если задачи в области внутренней безопасности не могут быть выполнены без применения силы, каждое государствоучастник будет обеспечивать, чтобы ее применение было соизмеримо с имеющейся потребностью в принудительных действиях. Вооруженные силы будут принимать должные меры с тем, чтобы избегать ущерба гражданским лицам или их имуществу.

37. Государства-участники не будут использовать вооруженные силы в целях ограничения мирного и законного осуществления прав человека и гражданских прав лицами, действующими в личном качестве либо в качестве представителей групп, или в целях лишения этих лиц их национальной, религиозной, культурной, языковой или этнической самобытности.

В соответствии с пунктом 25.4 Копенгагенского документа в отношении упомянутого выше принципа недискриминации в пункте 17 Кодекса поведения содержится предупреждение о том, что нарушения прав человека и основных свобод может стать источником политической напряженности и что это может поставить под угрозу мир и безопасность. Согласно положениям данного пункта, такие нарушения могут включать «проявления агрессивного национализма, расизма, шовинизма, ксенофобии и антисемитизма».

Наконец, Кодекс содержит положения, касающиеся непосредственно чрезвычайного положения, применимые в чрезвычайных ситуациях в области общественного здравоохранения, таким как коронавирусный кризис. Государства-участники, использующие вооруженные силы и силы безопасности в условиях чрезвычайного положения, должны:

а) четко определять функции и задачи таких сил, а также их обязанность действовать исключительно в конституционных рамках (пункт 21);

b) обеспечивать, чтобы личный состав военных и военизированные сил, а также сил безопасности мог пользоваться правами человека и основными свободами (пункты 3, 32);

c) обеспечивать политический нейтралитет вооруженных сил как института (пункт 23);

d) предотвращать случайное или несанкционированное использование военных средств (пункт 24);

е) обеспечивать индивидуальную ответственность военнослужащих за их действия согласно национальному законодательству и международному праву (пункт 30);

f) придерживаться принципа, согласно которому ответственность вышестоящих лиц не освобождает подчиненных от их собственной индивидуальной ответственности (пункт 31), в частности, в контексте гуманитарного права и законодательства, гарантирующего уважение прав человека. 
Что касается применения Кодекса, то решение Форума ОБСЕ по сотрудничеству в области безопасности обязывает государства-участников ежегодно обмениваться информацией о выполнении его положений ${ }^{152}$, включая возможность добровольного представления докладов по факультативным вопросам. Швейцария при обмене информацией в 2020 году воспользовалась этой возможностью, добровольно включив в представленную ею информацию короткую главу «Меры по борьбе с коронавирусом». В ней, в частности, подчеркивается, что все меры, принятые на национальном уровне в ответ на пандемию, соответствуют положениям, содержащимся в пунктах 24 и 25 Копенгагенского документа и в пункте 28 Московского документа. Кроме того, в связи с ежегодным обсуждением выполнения Кодекса поведения в июне 2020 года постоянное представительство Швейцарии при ОБСЕ предложило всем государствам-участникам воспользоваться ежегодным обменом информацией для обмена извлеченными уроками и передовым опытом в отношении использования вооруженных сил во время коронавирусного кризиса ${ }^{153}$.

\section{Чрезвычайное положение и применение вооруженных сил во время пандемии COVID-19}

С начала коронавирусного кризиса более трети государств-участников ОБСЕ официально объявили предусмотренное международным правом чрезвычайное положение, в то время как другие ввели иные чрезвычайные режимы различной интенсивности или ограничительные меры, приняв соответствующие законы или политические решения ${ }^{154} .28$ государств-участников проинформировали БДИПЧ о том, что в ответ на пандемию они приняли чрезвычайные меры ${ }^{155}$. Принятые государствами чрезвычайные меры привели к отступлению от обязательств относительно уважения прав человека и основных свобод, включая свободу собраний и ассоциаций, свободу передвижения, права на свободу, справедливое судебное разбирательство, уважение частной и семейной жизни, на безопасность, свободу мысли, совести и религии, права на собственность, образование, а в некоторых случаях - свободу выражения мнений и запрет на пытки и жестокое обращение. В некоторых странах, например, в Венгрии, введено бессрочное чрезвычайное положение без предусмотренных Копенгагенским документом временных ограничений ${ }^{156}$. Кроме того, чрезвычайные меры создали проблемы в том, что касается демократического контроля и функционирования парламентов, транспарентности, неприкосновенности частной жизни (включая защиту личных данных), институтов правосудия, свободных и справедливых выборов, а также борьбы с преступлениями на почве ненависти и дискриминацией ${ }^{157}$.

Во всем регионе ОБСЕ государства-участники стали свидетелями милитаризации общественной сферы - события, не имевшего прецедента в последнее время в большинстве государств-участников ОБСЕ. Политики высокого уровня широко ис- 
пользовали в своем политическом лексиконе военные метафоры. Их публичные заявления изобилуют ссылками на сражения, невидимых врагов и аналогии с войной и военными победами. Хотя подобный дискурс может помочь подчеркнуть остроту проблемы, приостановить межпартийную рознь, укрепить солидарность и мобилизовать ресурсы, он также может ослабить плюрализм, подорвать демократические процедуры и препятствовать международной солидарности ${ }^{158}$. Милитаристские формулировки также прокладывают путь как для оправданного, так и для необоснованного использования вооруженных сил при преодолении кризиса.

Исторически сложилось так, что военные играли существенную роль в обуздании пандемий, начиная с гриппа-испанки 1918 года ${ }^{159}$ и заканчивая пандемией H1N1 в 2009 году ${ }^{160}$. Вооруженные силы, обладающие непревзойденным потенциалом в области регулирования кризисов, инфраструктурой для проведения научных исследований и опытно-конструкторских работ, дисциплиной, авторитетом, системами управления, - естественный партнер гражданских властей в чрезвычайных ситуациях, в том числе в области общественного здравоохранения. Поэтому неудивительно, что во время коронавирусного кризиса помощь военных гражданским властям сыграла важнейшую роль во всем регионе ОБСЕ. В некоторых государствах-участниках это включало такие крупномасштабные операции, как «Устойчивость» (Resilience) во Франции, «Балмис» в Испании и «Ограничение» (Restrict) в Соединенном Королевстве. В то время как в большинстве стран вооруженные силы были использованы «в соответствии с конституционными процедурами» (пункт 36 Кодекса поведения), были и исключения. Например, в Сербии и Албании парламенты были отодвинуты на второй план, а исполнительная власть не добивалась своевременного утверждения ее мер ${ }^{161}$.

В регионе ОБСЕ военные были мобилизованы для решения различных задач, которые можно сгруппировать по пяти основным категориям (см. таблицу 1). 
Таблица 1: Задачи, решавщиеся вооруженными силами государств-участников ОБСЕ в период коронавирусного кризиса

\begin{tabular}{|c|c|c|c|c|}
\hline $\begin{array}{l}\text { Логистика и } \\
\text { перевозки }\end{array}$ & $\begin{array}{l}\text { Медицинская } \\
\text { поддержка }\end{array}$ & $\begin{array}{l}\text { Исследования и } \\
\text { разработки }\end{array}$ & $\begin{array}{l}\text { Поддержка орга- } \\
\text { нов государствен- } \\
\text { ного управления }\end{array}$ & $\begin{array}{l}\text { Внутренняя } \\
\text { безопасность }\end{array}$ \\
\hline $\begin{array}{ll}\text { • } & \text { Репатриация } \\
\text { • } & \text { граждан } \\
\text { Гуманитарная } & \text { помощь } \\
\text { • } & \text { Международная } \\
\text { помощь } & \text { Перевозка паци- } \\
\text { ентов, медперсо- } \\
\text { нала и средств } \\
\text { индивидуальной } \\
\text { защиты }\end{array}$ & $\begin{array}{ll}\text { • } & \text { Дезинфекция } \\
\text { общественных } \\
\text { пространств } \\
\text { Производство } \\
\text { средств индиви- } \\
\text { дуальной защи- } \\
\text { ты } \\
\text { •троительство } \\
\text { полевых госпи- } \\
\text { талей и управле- } \\
\text { ние ими } \\
\text { Тестирование и } \\
\text { отслеживание } \\
\text { контактов } \\
\text { Предоставление } \\
\text { военно-меди- } \\
\text { цинского персо- } \\
\text { нала, средств } \\
\text { индивидуальной } \\
\text { защиты, инфра- } \\
\text { структуры и } \\
\text { оборудования } \\
\text { поддержание ра- } \\
\text { боты моргов }\end{array}$ & $\begin{array}{ll}\text { • } & \text { Разработка и } \\
\text { испытания } \\
\text { вакцин } \\
\text { Производство } \\
\text { дезинфициру- } \\
\text { ющих средств } \\
\text { • Разработка } \\
\text { приложений } \\
\text { для отслежи- } \\
\text { вания } \\
\text { Производство } \\
\text { средств инди- } \\
\text { видуальной } \\
\text { защиты }\end{array}$ & $\begin{array}{ll}\text { • } & \text { Стратегические } \\
\text { - } & \text { воммуникации } \\
\text { Вовлечение } \\
\text { специалистов } \\
\text { по оборонному } \\
\text { планированию } \\
\text { в другие госу- } \\
\text { дарственные } \\
\text { органы } \\
\text { Поддержка от- } \\
\text { слеживания } \\
\text { контактов }\end{array}$ & $\begin{array}{ll}\text { • } & \text { Пограничный } \\
\text { контроль } \\
\text { Управление } \\
\text { миграцией - } \\
\text { поддержание } \\
\text { правопорядка } \\
\text { Обеспечение } \\
\text { соблюдения ка- } \\
\text { рантина } \\
\text { Охрана боль- } \\
\text { ниц, центров } \\
\text { пенсионного } \\
\text { обеспечения, } \\
\text { государствен- } \\
\text { ных предприя- } \\
\text { тий и критиче- } \\
\text { ской инфра- } \\
\text { структуры }\end{array}$ \\
\hline
\end{tabular}

Во-первых, государства-участники использовали свои вооруженные силы для материально-технического обеспечения и транспортировки. Это включает репатриацию граждан, оказавшихся за рубежом в качестве туристов или рабочих, и оказание гуманитарной помощи внутри страны, такой как доставка продуктов питания лицам, живущим в условиях нищеты (Албания) ${ }^{162}$, лицам, находящимся в карантине $(\text { Мальта) })^{163}$, и бездомным (Бельгия ${ }^{164}$. Кроме того, вооруженные силы принимали участие в отправке и получении международной помощи, в том числе в перевозке пациентов, медицинского персонала и средств индивидуальной защиты (СИЗ). Эта военная логистическая и транспортная деятельность не вызывает сомнений и не нарушает положения Кодекса и других базовых документов ОБСЕ.

Во-вторых, государства-участники использовали вооруженные силы для оказания медицинской помощзи, включая дезинфекцию общественных мест, производство СИЗ, развертывание полевых госпиталей и управление ими, проведение испытаний и отслеживание контактов, предоставление военно-медицинского персонала, СИЗ, инфраструктуры и оборудования, а также поддержание работы моргов. Хотя эти виды деятельности относительно бесспорны, они вызывают озабоченность в контексте Кодекса поведения. Прежде всего это связано с деятельностью, которая потен- 
циально может подвергнуть военнослужащих заражению и ставит вопрос о правах человека и основных свободах военнослужащих, особенно в том, что касается их здоровья и безопасности на рабочем месте (пункт 32 Кодекса). Во многих случаях сообщалось (как правило, союзами военных), что солдаты не имели надлежащей подготовки или достаточных средств индивидуальной защиты, что приводило к случаям их заболевания и смертям, которых можно было бы избежать ${ }^{165}$. Кроме того, участие военных в тестировании и использовании средств отслеживания людей вызывает обеспокоенность в связи с потенциальными нарушениями прав человека и возможностью отчуждения между гражданским населением и военными (пункты 2 и 7 Кодекса). В Словакии, например, вооруженные силы ввели обязательное тестирование цыганского населения, которое, по информации «Международной амнистии», только усугубило «стигматизацию и предрассудки, с которыми они и без того сталкивались» ${ }^{166}$.

В-третьих, вооруженные силы использовались для проведения научных исследований и разработок. Это включает в себя разработку и испытание вакцин, дезинфицирующих средств, средств отслеживания и СИЗ. Единственное пока в этой категории действие, идентифицированное как потенциальное нарушение Кодекса поведения (пункт 32$)$, - испытание вакцин на российских солдатах ${ }^{167}$. Хотя солдаты вызвались добровольно, это потенциально проблематично, так как вооруженные силы представляют собой иерархическую структуру, в которой давление, как прямое, так и косвенное, может помешать осознанному согласию ${ }^{168}$. Другие известные научноисследовательские и опытно-конструкторские работы, проводимые военными государств-участников ОБСЕ, с точки зрения соблюдения положений Кодекса, беспроблемны.

В-четвертых, государства-участники использовали свои вооруженные силы для поддержания системы государственного управления, осуществляемого другими органами власти. В Литве, например ${ }^{169}$, военные эксперты в области стратегических коммуникаций оказывали содействие гражданским властям в борьбе с дезинформацией и фальшивыми новостями ${ }^{170}$. Британские вооруженные силы предоставили военных специалистов по планированию местным органам власти для поддержки планирования и принятия решений ${ }^{171}$. В Ирландии военнослужащие сил обороны оказывали содействие органам здравоохранения в отслеживании контактов ${ }^{172}$. Специалисты по планированию вооруженных сил Нидерландов были прикомандированы к национальным антикризисным структурам, министерству здравоохранения и другим гражданским учреждениям в целях содействия координации ${ }^{173}$. Содействие, оказываемое вооруженными силами гражданским властям в таких и аналогичных случаях, беспроблемна до тех пор, пока эти силы «находятся под эффективным контролем конституционно учрежденных органов власти и с соблюдением принципа верховенства закона» (пункт 36 Кодекса) и пока они остаются политически нейтральными как институт (пункт 23). Во всех известных авторам случаях эти требования соблюдались, и в рассматриваемом регионе не было зафиксировано ни одно- 
го случая, когда военные органы принимали бы решения без гражданского демократического контроля.

Наконец, значительное число государств-участников использовали вооруженные силы для обеспечения внутренней безопасности. Сюда входят пограничный контроль, управление миграцией, поддержание правопорядка, карантинное обеспечение и охрана больниц, центров для престарелых, государственных предприятий и важнейших объектов инфраструктуры. Некоторые страны, такие как Германия и Великобритания, из-за конституционных ограничений и исторически деликатных вопросов воздержались от использования своих вооруженных сил для обеспечения внутренней безопасности ${ }^{174}$. В некоторых из тех государств, в которых на вооруженные силы возложено решение этих задач, сообщалось о чрезмерном применении силы. В Сербии, например, военная полиция была мобилизована для охраны центров для беженцев, в которых в период чрезвычайного положения содержалось около 9000 человек ${ }^{175}$. Сообщалось также, что в Ирландии и Нидерландах соискатели политического убежища содержатся под стражей на военных объектах ${ }^{176}$. Военные были также развернуты для охраны границ в нескольких государствах-участниках ОБСЕ, в том числе в Греции, Хорватии, Польше, Латвии, Литве, Нидерландах, Северной Македонии, Австрии, Португалии, Сербии, Словакии, Словении и Чешской Республике. Это привело к вовлечению вооруженных сил в столкновения с мигрантами и нарушениям прав человека. В Хорватии военные применяли силу против мигрантов на государственной границе, а в Словении военизированные группы патрулировали южную границу, пытаясь предотвратить въезд мигрантов ${ }^{177}$. Во многих государствах-участниках вооруженные силы использовались для обеспечения безопасности мест карантина, патрулирования улиц и охраны объектов. Хотя такая военная помощь гражданским властям в определенных контекстах приемлема, особенно если полицейский потенциал исчерпан, но в ряде таких случаев не было ясного обоснования или определения задач вооруженных сил, что вызывает озабоченность $^{178}$. В Венгрии ${ }^{179}$ и Сербии ${ }^{180}$ широкое использование вооруженных сил в целях обеспечения внутренней безопасности не всегда оправдывалось соображениями общественного здравоохранения и лишь усугубляло продолжающееся отступление от демократии, которое имеет место в этих странах.

\section{Заключение и рекомендации}

Пандемия COVID-19 застала мир врасплох. Она выявила слабые места, что сказалось на способности национальных правительств и международных организаций координировать усилия по своевременному ограничению распространения вируса и пропорциональному развертыванию своих сил и средств таким образом, чтобы последовательно обеспечивать уважение прав человека и основных свобод своих граждан. Более трети государств-участников объявили чрезвычайное положение, а 
некоторые применили необычайно драконовские, максимально ограничительные меры. Во всей европейской части региона ОБСЕ страны использовали вооруженные силы для обеспечения перевозок, медицинской помощи, научных исследований и разработок, оказания содействия органам государственного управления и обеспечения внутренней безопасности.

Хотя использование вооруженных сил, как правило, было оправданно и бесспорно, в некоторых случаях, особенно в плане обеспечения внутренней безопасности, оно не соответствовало положениям Кодекса поведения ОБСЕ. Деятельность, осуществляемая вооруженными силами в современных развитых государствах, должна основываться на верховенстве права и прочно укоренившейся, четко определенной правовой базе. Вооруженные силы - это стратегические резервы и «силовые активы», которые государства могут использовать для законной защиты от внешних врагов, обеспечения принуждения к миру и поддержания мира в рамках мандатов, предоставленных им Советом безопасности ООН. Поэтому вооруженные силы структурно плохо приспособлены для решения внутренних невоенных проблем, таких как коронавирусный кризис, о чем свидетельствуют приведенные выше примеры ненадлежащего поведения и превышения полномочий.

Использование вооруженных сил в чрезвычайных ситуациях и в условиях чрезвычайного положения, а также степень надлежащего парламентского и демократического контроля над их использованием - важная лакмусовая бумажка для проверки приверженности общества демократическим стандартам (и обязательствам его политического руководства). Нарушения при использовании вооруженных сил во время кризиса COVID-19 - симптомы глубоких системных проблем управления. Если эти нарушения можно было бы объяснить только плохой реализацией, стрессом и отсутствием опыта, то в будущем можно было бы избежать повторения ошибок и неудач, организовав процессы тщательной оценки и извлечения уроков под руководством политических и парламентских деятелей. Вместе с тем, если они были обусловлены общими сбоями в функционировании органов государственного управления, то они свидетельствуют о слабости демократических институтов и (или) демократической политической культуры. Таким образом, коронавирусный кризис может стать лакмусовой бумажкой для определения состояния и качества демократического управления во всем регионе. В этой связи мы можем также сослаться на пункт 20 Кодекса поведения, в частности на его заключительное положение о том, что государства-участники «будут содействовать интеграции своих вооруженных сил с гражданским обществом в качестве важного проявления демократии».

Любые политические рекомендации на данном этапе коронавирусного кризиса в условиях, когда вторая волна поразила государства-участники ОБСЕ при отсутствии вакцины - могут быть только предварительными. Тем не менее, анализ недавнего использования вооруженных сил в ответ на коронавирусный кризис через призму норм и принципов, закрепленных в Кодексе поведения, позволяет высказать 
ряд предварительных рекомендаций, которые должны быть приняты во внимание ОБСЕ и ее государствами-участниками:

- Чрезвычайные меры и использование вооруженных сил должны осуществляться в конституционных рамках государств и полностью под демократическим парламентским и гражданским контролем. Государства-участники ОБСЕ должны выполнять соответствующие нормы и положения Копенгагенского документа 1990 года, Московского документа Конференции по человеческому измерению безопасности 1991 года, документа хельсинкского саммита 1992 года и Кодекса поведения ОБСЕ, касающегося военно-политических аспектов безопасности 1994 года.

- Органы, создаваемые для борьбы с COVID-19, должны представлять собой специальные правительственные структуры, возглавляемые главами правительств или министрами здравоохранения, а не министерствами обороны. При оказании содействия гражданским властям в условиях пандемии или решении иных невоенных задач вооруженные силы должны играть строго вспомогательную роль и подчиняться гражданскому органу.

- Компетентная и четкая иерархия, специально разработанные правила поведения и (или) правила применения вооруженных сил имеют первостепенное значение для обеспечения их эффективного развертывания в гражданской среде и продуктивного взаимодействия между вооруженными силами и гражданским населениeм.

- На национальном, региональном и местном уровнях должны регулярно проводиться совместная подготовка и учения всех учреждений и ведомств, имеющих отношение к реагированию на чрезвычайные ситуации и оказанию помощи в случае стихийных бедствий, что повысит эффективность и действенность их мер реагирования. На различных уровнях управления необходимо выработать общее понимание вертикального взаимодействия с четким перечнем возлагаемых на каждый уровень задач в соответствии с принципом субсидиарности.

- Военнослужащие, развернутые во время пандемии, должны быть обучены и экипированы таким образом, чтобы свести к минимуму распространение инфекции. Военная деятельность, не имеющая отношения к национальной безопасности или территориальной обороне (продолжающийся конфликт, оборона от вооруженного нападения и так далее) или которая не может быть организована в полном соответствии с медико-санитарными нормами, должна быть приостановлена или сокращена.

- В рамках прохождения службы военнослужащие должны иметь возможность осуществлять свои права и основные свободы, которые включают физическую неприкосновенности каждого военнослужащего. Военнослужащие не должны подвергаться неоправданному воздействию биологических угроз, а если это необходимо, то они должны быть надлежащим образом защищены. Кроме того, 
военнослужащим не следует приказывать «добровольно» испытывать на себе новые вакцины или лекарства, что было бы явным злоупотреблением военной иерархией.

- Ежегодный обмен информацией о выполнении Кодекса поведения, который считается частью инструментария ОБСЕ в сфере мер укрепления доверия и безопасности, должен более широко использоваться в качестве платформы для обмена информацией о том, как государства-участники справляются с чрезвычайной ситуацией, вызванной пандемией, и о том, как при этом соблюдаются нормы и положения Кодекса ${ }^{181}$.

- Государства-участники ОБСЕ, а также секретариат ОБСЕ должны активизировать свои усилия по повышению осведомленности о важности Кодекса поведения. За последние годы актуальность ОБСЕ в глазах многих государств-участников, к сожалению, снизилась, а многие документы ОБСЕ недостаточно известны. Это означает, что правительства могут планировать использование вооруженных сил в чрезвычайных ситуациях, не сверяясь при этом с Кодексом поведения как с ключевым нормативным документом.

- Следует и далее поощрять и активизировать проведение в регионе ОБСЕ семинаров, практикумов и других мероприятий, направленных на универсальное ознакомление государств-участников с Кодексом поведения. Кроме того, раздел, посвященный осуществлению положений Кодекса в чрезвычайных ситуациях и в условиях чрезвычайного положения, можно было бы включить в пересмотренный вариант «Подборки практических примеров демократического контроля над вооруженными силами», которая представляет собой руководство по передовой практике осуществления Кодекса поведения в регионе ОБСЕ ${ }^{182}$.

- Чрезвычайные меры и проблема их пропорционального применения, как показал коронавирусный кризис, не являются чем-то новым. Они отражают более общие недостатки, особенно в странах с ранее существовавшими проблемами в области управления. Несколько государств-участников уже объявили о своем намерении провести тщательную самооценку своих мер реагирования на COVID-19. Такая оценка должна быть проведена в отношении действий всех исполнительных органов власти, как гражданских, так и военных, и должна охватывать всех участников, начиная с высшего уровня командования и управления и заканчивая полицейским и военным персоналом на местах. Она должна быть направлена на определение того, в какой степени данные структуры соблюдают принципы соразмерности и причиняют наименьший возможный ущерб.

- БДИПЧ могло бы помочь государствам-участникам в проведении таких оценок и самооценок, опираясь на общие концепции и прошлый опыт. После проведения оценки ситуации в регионе ОБСЕ БДИПЧ могло бы предоставить общие рекомендации всем государствам-участникам, опубликовав руководство по передовой практике парламентского демократического контроля над вооруженными силами во время чрезвычайного положения и чрезвычайных ситуаций. Кроме 
того, БДИПЧ следует предоставить возможность поделиться выводами, которые оно сделает, оценивая опыт в масштабах всей ОБСЕ, путем подготовки индивидуальных рекомендаций для отдельных государств-участников в ответ на их соответствующие запросы.

\section{Примечания}

144 Авторы хотели бы поблагодарить анонимных рецензентов за их ценные замечания по более ранней версии этой рукописи.

145 Кодекс поведения, касающийся военно-политических аспектов безопасности. DOC.FSC/ 1/95, 3 декабря 1994 // Официальный сайт ОБСЕ. URL: https://www.osce.org/files/f/documen ts/d/f/41359.pdf.

14620 years of OSCE Code of Conduct on Politico-Military Aspects of Security / P. Chaudhuri P., A. Lambert, T. Schmidt T. (eds). - Swiss Armed Forces, 2015. URL: https://www.osce.org/files/ f/documents/8/4/128961.pdf.

147 Документ Московского совещания Конференции по человеческому измерению СБСЕ, 3 октября 1991 // Официальный сайт ОБСЕ. URL: https://www.osce.org/files/f/documents/8/a/1 4314.pdf.

148 В 1995 году Совещание по безопасности и сотрудничеству в Европе (СБСЕ) было переименовано в Организацию по безопасности и сотрудничеству в Европе (ОБСЕ).

149 Хельсинкский документ 1992 года. Вызов времени перемен, 9-10 июля 1992 // Официальный сайт ОБСЕ. URL: https://www.osce.org/files/f/documents/8/0/39534.pdf.

150 Документ Копенгагенского совещания Конференции по человеческому измерению СБСЕ, 29 июня 1990. // Официальный сайт ОБСЕ. URL: https://www.osce.org/files/f/documents/d/0/ 14305.pdf.

151 Дополнительные международные нормы, применимые в государствах-участниках ОБСЕ, содержатся в Международном пакте о гражданских и политических правах (пункты 12, 17, 21), Европейской конвенции о защите прав человека и основных свобод (пункты 8,11 ) и в пункте 2 Протокола № 4 к Европейской конвенции.

152 Форум по сотрудничеству в области безопасности. Решение № 2/09. Техническое обновление вопросника по Кодексу поведения. FSC.DEC/2/09, 1 апреля 2009 // Официальный сайт ОБСE. URL: https://www.osce.org/files/f/documents/5/e/36752.pdf.

153 См.: Permanent Mission of Switzerland to the Organization for Security and Co-operation in Europe (OSCE), the United Nations and to the International Organizations in Vienna. Information Exchange on the Code of Conduct on Politico-Military Aspects of Security. Note 21/2020OSCE, FSC.EMI/75/20, 15 April 2020. P. 18. URL: https://www.osce.org/files/f/documents/8/3/ 450214.pdf.

154 Данные БДИПЧ на момент завершения статьи см.: OSCE Human Dimension Commitments and State Responses to the Covid-19 Pandemic // Официальный сайт ОБСЕ. 2020. 17 July. P. 20. URL: https://www.osce.org/odihr/human-rights-states-of-emergency-covid19.

155 Ibidem. P. 11.

156 Ibidem. P. 36.

157 Ibidem.

158 Van Rythoven E. What's wrong with the war metaphor // Duck of Minerva. 2020. 5 April. URL: https://duckofminerva.com/2020/04/whats-wrong-with-the-war-metaphor.html. 
159 Watterson C., Kamradt-Scott A. Fighting Flu: Securitization and the Military Role in Combating Influenza // Armed Forces \& Society. 2016. No 1. P. 145-168.

160 Molina H.V. et al. The Military Role in a Flu Pandemic // Harefuah. 2010. No 1. P. 9.

161 Đokić K. The armed forces against COVID-19 in the Western Balkans: One invisible enemy and a few visible flaws // European Western Balkans. 2020. 5 May 2020. URL: https://europeanwest ernbalkans.com/2020/05/05/the-armed-forces-against-covid-19-in-the-western-balkans-one-invis ible-enemy-and-a-few-visible-flaws/.

162 COVID-19, FA vijojnë angazhimin në operacionin humanitar dhe në monitorim/patrullim në gjithë vendin // Republic of Albania, Armed Forces. 2020. 15 prill. URL: https://aaf.mil.al/te-fun dit/5514-covid-19-fa-vijojne-angazhimin-ne-operacionin-humanitar-dhe-ne-monitorim-patrullim -ne-gjithe-vendin.

163 Soldiers delivering groceries to people in quarantine, CPD assisting police in spot checks // Malta Independent. 2020. 16 March. URL: https://www.independent.com.mt/articles/2020-03-16/loc al-news/Soldiers-delivering-groceries-to-people-in-quarantine-CPD-assisting-police-in-spot-chec ks-6736220894.

164 CORONA - What are the Belgian Armed Forces doing in the fight against Covid-19? // EUROMIL. 2020. March. URL: http://euromil.org/wp-content/uploads/2020/03/Corona-What-are-t he-Belgian-Armed-Forces-doing.pdf.

165 См.: к примеру, доклад Объединенной ассоциации военных Испании: INFORME Situación del COVID-19 en Fuerzas Armadas ¿QUIÉN PROTEJE AL QUE PROTEJE? // EUROMIL. 2020. 2 April. URL: http://euromil.org/wp-content/uploads/2020/04/200402-Informe-AUME-pre vención-COVID-19.pdf.

166 Amnesty International: Roma must not be further stigmatized during COVID-19 // EUR 72/2110/2020. 2020. 8 April. URL: https://www.amnesty.org/download/Documents/EUR7 221102020 ENGLISH.PDF.

167 Russia's coronavirus vaccine 'ready', military says // The Moscow Times. 2020. 21 July. URL: https://www.themoscowtimes.com/2020/07/21/russias-coronavirus-vaccine-ready-military-saysa70941.

168 Russia's coronavirus vaccine trials have a few problems // Meduza. 2020. 5 June. https://meduza .io/en/feature/2020/06/06/russia-s-coronavirus-vaccine-trials-have-a-few-key-problems

169 Frequently asked questions about the Lithuanian Armed Forces in the context of COVID19 // Republic of Lithuania, Ministry of National Defence, 2020. 14 April. URL: https://kam.lt/en/new s_1098/current_issues/frequently_asked_questions_about_the_lithuanian_armed_forces_and_co vid19.html.

170 MOD team to tackle coronavirus fake news and scams // Forces. 2020. 9 April. URL: https://ww w.forces.net/news/mod-team-tackle-coronavirus-fake-news-and-scams.

171 Pepe E., Lapo A. Europe's armed forces and the fight against COVID-19 // IISS/ 2020. 9 April. URL: https://www.iiss.org/blogs/military-balance/2020/04/europe-armed-forces-covid-19.

17280 Defence Forces cadets are being trained in Covid-19 contact tracing // The Journal. 2020. 13 March. URL: https://www.thejournal.ie/defence-forces-cadets-trained-in-coronavirus-contact-tra cing-5046020-Mar2020/.

173 Deployment of the Netherlands Ministry of Defence in the Fight against COVID-19, 11 March1 July // Government of the Netherlands, Ministry of Defence. URL: https://english.defensie.nl/t opics/corona-covid-19.

174 Pepe E., Lapo A. Op. cit.

175 Kovačević N. Deprivation of liberty of refugees, asylum seekers and migrants in the Republic of Serbia through measures of restriction and measures of derogation from human and minority rights made under the auspices of the state of emergency // A 11 - Initiative for Economic and 
Social Rights. 2020. 16 March. URL: https://www.a11initiative.org/wp-content/uploads/2020/05 /Deprivation-of-liberty-of-refugees.pdf.

176 Akkerman M. COVID-19 and Border Politics // Border Wars Briefing 1, Transnational Institute/ Stop Wapenhandel, July 2020. URL: https://www.tni.org/files/publication-downloads/tni-covid19-and-border-politics-brief.pdf.

177 Stojanović D. Vigilantes in Slovenia patrol borders to keep out migrants // AP. 2019. 17 September. URL: https://apnews.com/57424e6bf60046e594b4c052bac86b6c.

178 Akkerman M. Op. cit.

179 Hungarian 'militarisation' under Orban stirs concern // Balkaninsight. 2020. 29 July. URL: https: //balkaninsight.com/2020/07/29/hungarian-militarisation-under-orban-stirs-concern/.

180 Ejdus F. Pandemijske lekcije za politiku i system odbrane Republike Srbije // MONS. 2020. 7 May. URL: http://mons.rs/pandemijske-lekcije-za-politiku-i-sistem-odbrane-republike-srbije.

181 См. также: OSCE Human Dimension Commitments and State Responses to the Covid-19 Pandemic, 2020. P. 20.

182 Annual discussion on the implementation of the Code of Conduct on politico-military aspects of security, Consolidated Report. FSC.GAL/96/14, 24 July 2014 // Официальный сайт ОБСЕ. URL: http://www.osce.org/fsc/121796 